April 2018

\title{
"I Forgive to Forget": Implications for Community Restoration and Unity in Northern Uganda
}

Julaina A. Obika

Gulu University, j.obika@gu.ac.ug

Emilio Ovuga

Gulu University, emilio.ovuga@gmail.com

Follow this and additional works at: https://digitalcommons.usf.edu/jacaps

Part of the Peace and Conflict Studies Commons, and the Political Science Commons

\section{Recommended Citation}

Obika, Julaina A. and Ovuga, Emilio (2018) "'I Forgive to Forget": Implications for Community Restoration and Unity in Northern Uganda," Journal of African Conflicts and Peace Studies: Vol. 4: Iss. 1, . DOI: https://doi.org/10.5038/2325-484X.4.1.1035

Available at: https://digitalcommons.usf.edu/jacaps/vol4/iss1/5

This Article is brought to you for free and open access by the Open Access Journals at Digital Commons @ University of South Florida. It has been accepted for inclusion in Journal of African Conflicts and Peace Studies by an authorized editor of Digital Commons @ University of South Florida. For more information, please contact digitalcommons@usf.edu. 


\section{Introduction}

Northern Uganda has experienced over ten years of relative peace since the beginning of the peace talks and cessation of hostilities between the incumbent government and the Lord's Resistance Army in 2006. Although a final peace agreement has not been signed, the internally displaced persons' (IDP) camps were decommissioned and people told to return home. The war in northern Uganda has been well documented - its causes and the actors (see Allen 2006; Allen \& Vlassenroot 2010; Atkinson 2009; Finnstrom 2008), as well as the untold suffering that unarmed civilians, men, women and children have gone through as a result (see de Temmerman 2001; Dolan 2009; Eichsraedt 2009; Green 2008; Ovuga, Oyok \& Moro 2008).

In the aftermath of the war, stability and unity appear to have returned to communities as a result of the relative peace in the region. The shared experience among the people of northern Uganda of having been wronged by, or having wronged others could be one of the reasons that stability has been achieved. During the two decades war the people of northern Uganda were wronged in various ways at personal and community levels. Many were wronged as a direct result of the war: e.g. death of loved ones, abduction, maiming and separation of family and social networks, while others continue to experience wrongs in their day to day interaction with family, partners, friends and relatives, e.g. domestic violence and abuse, verbal insults and betrayal and today, land conflicts being fought between kith and kin. There is therefore an urgent need to overcome experiences of harm in order to break the cycles of violence. We believe that one way of achieving this is through forgiveness, a practice that has come to be accepted and embraced by the people of Acholi.

In recent years a lot of focus has been put on the study of reconciliation and forgiveness as a means of conflict transformation and peacebuilding. A lot has been documented on forgiveness - its meaning, processes and consequences/implications for interpersonal relationships, personal peace as well as mental and physical health (see Fincham 2001; McCoullough \& Witvliet 2002; Orcutt et al. 2005; Staub et al 2005; Wade and Worthington 2005; Witvliet et al. 2001). The present study sought to understand and question the processes of forgiveness and enhance the creation of space within which people in Awach sub-County and Gulu town in Gulu District can forgive and be forgiven for the wrongs they have suffered or caused to fellow human beings within the ambit of their daily lives before, during and after the war. As people rebuild their lives, the study also sought to explore how peace within larger communities could be consolidated through the acts and practices of forgiveness at the individual level.

There are national and community level frameworks that have created space for forgiveness and reconciliation in northern Uganda. At the national level, The Amnesty Act, 2000, (amended in 2002 and 2006), has offered a comprehensive amnesty to members of former armed groups who have renounced rebellion against the government and wish to be reintegrated into their communities (Amnesty Commission 2009). At the community level, there are several traditional rituals that have been performed for the same purpose. One that is widely documented is the Mato Oput, a ritual that is performed particularly when a murder has been committed and families or clans wish to forgive and reconcile after the fact, and avoid acts of revenge.

This ritual has given families and communities a space for re-establishing and rebuilding broken relationships. Some NGOs have sometimes been involved in funding 
'traditional' forgiveness and reconciliation rituals that mainly deal with the collective or community level processes.

According to Finnegan (2010:426), this has in a way promoted a kind of 'political forgiveness', which has seen the process of forgiveness occurring between collective groups of people. She argues that forgiveness has been legitimised and presented as a "viable option", particularly for the Acholi people because of war fatigue. She cites Finnstrom (2008) who explained, "compensation and reconciliation rather than revenge is the institutionalised Acholi way of handling disputes, homicides and unnatural deaths." Finnegan, however, highlights that the embodiment of forgiveness within the Acholi society is not universal, and the degree to which it is practiced and desired is contested. The only way for forgiveness to be effective and sustainable, therefore, is if it is chosen freely by the actors and not prescribed by intervening institutions. Besides, the practice of Mato oput does not lend itself to addressing the experience of wrongs that individuals experience at interpersonal levels within households and families, as it does not address emotional experiences that accompany wrongs.

The return process which began in 2008 following the signing of the cessation of hostilities in 2006 to end two decades of armed conflict and violence, has ushered in the end of human suffering and encampment. This beginning brought with it a new hope for people to piece their lives together, rebuild social ties and mend fractured interpersonal relationships. Faced with several challenges within interpersonal relationships, we believe that this view of forgiveness is relevant in northern Uganda where many people have had to deal with living with their former 'tormentors' e.g. those who had abducted them or killed their loved ones during the war, and have now been reintegrated into the same communities. Even today, people may have personal 'tormentors' in the forms of husbands, wives, parents, children, relatives and friends who continue to wrong them by being verbally or physically abusive. The fact that the guns went silent does not mean total peace.

Many clans, families and individuals are involved in land disputes, which have become pervasive as a direct result of the war and the encampment period during which people had to move away from their land for personal security. The war, having created 'unclear' land boundaries, led to a plethora of in-house fighting, land grabbing and desperation. Many women and children experience domestic violence, neglect and abuse, as well as gender-based violence. Suicide and suicidal behaviour, and alcohol abuse arising from psychosocial crises are a new challenge to social stability and are a source of public concern in Gulu District. We most certainly do not contend that forgiveness is a panacea for the current situation in northern Uganda, or that perpetrators should not be held accountable for their misdeeds, however, we have found that many close relationships are at a precipice and people want to harness their personal, inherent abilities to forgive and break the cycle of hurt and wrong doing in a bid to build a sustainable peace.

Against this background, we conducted the present study to determine the possibilities of building peace through forgiveness beginning with the individual and eventually spreading to the larger community.

The study focused on individual levels of forgiveness (local understanding, processes, practices and implications) and the relevance of this in the on-going peacebuilding efforts in northern Uganda. We examined forgiveness not only as a strategic act to end 
violence, but also as a vehicle and vital individual process that can foster both personal and community peace and unity.

\section{Theoretical underpinnings}

The stability and security of many societies around the world has been shattered as a result of war, violence and human rights abuses that cause untold suffering. The urgent task is for people to rebuild their lives and work towards the achievement of a sustainable peace for the future, by dealing with painful memories of the past (Barros, 2001).

The claim for justice is a widespread discourse and academics, human rights activists and survivors of human rights abuses agree on the benefits that can be accrued in the process of dealing with the past. In northern Uganda, there has been a debate about retributive and restorative justice mechanisms and how these can be used to achieve sustainable peace. Barros (2001:10) highlights some of the loopholes of retributive justice in meting the needs of the victims and societies at large. The tribunals set up in Rwanda after the 1994 genocide, for example, still have victims waiting to receive justice. There is also the challenge of certain horrible experiences such as destruction of souls, deprivation of childhood and erasure of dreams, which do not constitute crimes under domestic or international law but have serious mental health consequences for affected individuals. On this note, many perpetrators of such crimes within the private confines of households can go unpunished if retributive justice is not matched with other mechanisms. Barros however supports the views of African writers (Mahmood Mamdani and Wole Soyinka) who prefer social justice as a mechanism to promote national reconciliation and unity in broken societies.

According to Summerfield (2002:1106), the 21 official truth commissions established around the world since 1974 to document state terror and atrocity have grappled with concepts of reparation and reconciliation. After the devastating effects of the Nazi Holocaust, these commissions sought to create a public narrative of acknowledgment, and give victims a cathartic experience by speaking out publicly. Many survivors of gross human rights abuses have testified to a reduction in their suffering through the recounting of their traumatic experiences, although this subject has also been contested, with some arguing that the attainment of truth and remembrance of the past may become "obstacles" to the achievement of healing and reconciliation (Barros, 2001).

According to Barros, the process of remembering also supposes a dialogue about different experiences, memories and accounts of the past, providing a basis for the construction of a "collective narrative of historical memory". These different voices, recounting experiences, can then help to reshape and construct a future. For some, however, revealing is not necessarily healing, and remembering is not necessarily a liberating experience but can be one helpful way for victims to get closure. Hamber and Wilson (2002) argue that trauma is both immeasurable and ineffable and recovery from trauma is many times obstructed by the unlikelihood of justice during transition.

Neither retributive nor restorative justice offers effective remedies for emotional and psychological distress, anguish and suffering in victims wronged within the contexts of war and interpersonal relationships.

Memory is a compilation of referential fragments, constructs and vignettes, and in a world marked by malice, many of these bear the traces of trauma and offense (Larocco, 
2011:4). Forgiveness however is a quiet way of launching an assault on such malice. Forgiveness can remove the hold that a hurtful experience has on relationships, narratives and memory, and transform them for the better. Forgiveness does not alter the meaning or significance of the hurtful experience but instead reduces the power that it has over the forgiver (Larocco, 2011). According to Theidon (2000:541), memory is central to knowing who we are, what we have done and why and what sort of stories we tell about our past, which affects how the future is reconstructed. Forgiveness offers the means by which painful stories are integrated into the personhood of victims of hurtful experiences, and leads to personal growth and liberation from psychological and emotional pain arising from traumatic experiences in interpersonal relationships.

Graybill (2004) discusses three different ways in which nations deal with political transitions and memory. In the case of South Africa, the Truth and Reconciliation Commission (TRC) was set up and reconciliation and restorative justice promoted. In Rwanda, the new government after the genocide sought retributive justice by establishing tribunals and convicting many supporters of the genocide. Later on however, the government restored the Gacaca courts that promoted restorative justice. Mozambique on the other hand, according to Graybill, chose an 'amnesia' approach. They chose to forget about the past (particularly the civil war with the Renamo forces). There were no reported calls for justice for the victims or accountability and punishment for the perpetrators of human rights violations. The Mozambicans, however, dealt with their problems through traditional healing ceremonies.

Though the concept of forgiveness was often treated as a subject exclusively discussed by theologians and philosophers, (Fincham, 2000; Toussaint et al. 2001: 249) this perception has changed over the years gaining notable interest in the social sciences, and according to Hamber (2007), has become integrally linked to questions of transitional justice at the wider community level with its discussion at the interpersonal level being limited. It is therefore of interest to investigate the role of interpersonal level forgiveness for social harmony in the face of violations of individual rights at domestic and household levels.

Although no universal definition of forgiveness exists, many researchers agree that it involves "letting go" of negative effects directed towards the offender, giving up one's rights to retribution and exhibiting more positive and human responses towards the offender (Orcutt et al. 2005; Staub et al. 2005; Toussaint et al; Wade \& Worthington 2005:165; Witvliet et al 2001). Finnegan (2010) defines it as a "social process in which victim(s) release resentment toward perpetrator(s) and yet acknowledge the wrong done to them." In trauma therapy, the cathartic effect of forgiveness comes from the process of validation in which the aggrieved shares his/her traumatic experience with the therapist (Herman, 1992) and thus gives up resentment toward the offender in order to move on.

Forgiveness is a process in which people find meaning in their traumatic painful experiences and use that experience to transform grief or pain into good.

Anusiem (2011) gives an African perspective on forgiveness asserting that it is a communal act, the overlooking of which can have disastrous consequences. Such wrongs that call for communal involvement in the forgiveness processes include: wilful taking of life; sexual misconduct; assault; destructive jealousy and greed. In many African settings, each person is related to everyone in the community (through lineages, 
clans and kinships), and individual identity is of lower value than communal identity; individuals exist and derive meaning from their existence in relation to the wider community (Tutu, 1999).

Anusiem (2011:125) cites Steve Biko (1978) who believed that our living together is not an accident but a deliberate act of God to make communities join in the quest to answer the various problems of life. South Africa's Archbishop Desmond Tutu's concept of Ubuntu emphasises the idea that human beings are inextricably bound together. Ubuntu, which derives from a Xhosa expression, promotes the idea that 'people are people through other people'. It connotes humanness and the notion that a well-functioning community is one in which people are able to recognise that their humanity is inextricably bound to that of others. It therefore justifies and promotes forgiveness, reconciliation and restorative justice over retributive justice (Avruch \& Vejarano, 2002; Graybill, 2004:1118).

The process of reconciliation may, however, become an ambiguous approach to peacebuilding by applying what may be therapeutically effective for the individual to the collective. Avruch and Vejarano (2002:41) argue that the success of South Africa's TRC was through the recognition of individual suffering which was a 'collectivized' memory and thus the construction of the 'national victim'. The authors cite Winslow (1997) who was sceptical of this view, asserting that while this may work in some ways, forgiveness and reconciliation at the collective level can occur at the expense of individual psychological healing.

The individual level must therefore be independent from the collective level of healing. The question then is whether individual level forgiveness should precede or follow the collective communal level forgiveness and reconciliation. The problem that is usually not recognized is that communal level forgiveness and reconciliation that leads to social stability may not meet the psychological and welfare needs of the individual, resulting in posttraumatic stress disorder, mass psychosis, suicide and alcohol abuse (Volkan, 2004). Genuine reconciliation is concerned with facing the difficult questions about the past and considering how any process of reconciliation might relate to retributive justice for the individual, their immediate family and society. Genuine reconciliation is not only about achieving individual and social 'harmony', but is a multifaceted and complex process that includes accounting for past crimes (Hamber, 2007:122).

Forgiveness, therefore, presents a conceptual controversy. Leading scholars have expressed concern about the need for conceptual clarity, making it of vital importance to know what forgiveness is not. Forgiveness is not condoning, excusing, forgetting, tolerating, ignoring, minimising or denying the offence or its reality (McCoullough \& Witvliet, 2002; Witvliet et al, 2001).

Forgiveness still allows for holding the offender responsible for the transgression. When people forgive, their responses (i.e. what they think, feel, want or how they behave), towards their offenders becomes more positive and pro-social (McCoullough \& Witvliet 2002:448).

Forgiveness is not reconciliation and although these two concepts are linked and have many times been used interchangeably, they are indeed distinct. There is a debate about whether there can be reconciliation without forgiveness or vice versa (Hamber, 2007:119), but it is also well documented that one can simultaneously forgive and 
decide to end a relationship (Wade \& Worthington, 2005:160). Forgiveness can be unilateral while reconciliation is always mutual, bilateral or multilateral (Finnegan, 2010:428). Reconciliation involves the restoration of violated trust and requires the goodwill of both or all partners. Thus, forgiveness must be present for reconciliation to occur, but forgiveness can occur completely in the absence of reconciliation. There may well be instances in which it is not safe or appropriate for an individual to reconcile with an offender (Orcutt et al, 2005:1005).

Confusing forgiveness with reconciliation may lead people to accept abusive relationships or retain negative emotions. Forgiveness can also occur and the victim can still hold the offender accountable, see the offender in realistic terms, and make wise decisions about whether to return to the relationship (Fincham, 2001; Wade \& Worthington, 2005). Staub et al. (2005) also believe that forgiveness without acknowledgement of responsibility for the offence may present challenges and be harmful to any relationship and personal health and welfare.

McCoullough and Witvliet (2002:446) assert that the tendency to retaliate or seek retribution after being insulted or victimised is deeply ingrained in the biological, psychological and cultural levels of human nature, through a norm of reciprocity i.e. responding to hurts by committing hurts equivalent to those that they have suffered. This, the authors believe, is the most rudimentary approach to dealing with a perceived injustice. An important point to note here is that many cultures around the world have attempted to codify the "law of retaliation" so that revenge is taken out of the hands of individuals and placed into the hands of an impartial third party.

One mechanism that can interrupt the cyclical nature of vengeance is forgiveness, an approach that helps people quell their natural negative responses to transgressors and become increasingly motivated to enact positive ones instead. When painful memories are not properly dealt with, there is a risk of future generations engaging in renewed cycles of violence. A 'chosen trauma', according to Graybill (2004:1127) and Volkan (2004) can be rekindled years later to this effect. Forgiveness and reconciliation makes it possible for society to integrate "chosen trauma" with "chosen glory" permitting aggrieved parties to live in harmony with victors.

Social relationships are often marred by interpersonal offenses. These offenses are committed by people we are often very close to and include betrayals, rejection, lies and insults (Witvliet et al, 2001). Fincham (2000:1), using the metaphor, "kiss of the porcupines" described two fundamental assumptions about humans - they harm each other and they are social animals. This presents a challenge of how to maintain close relationships with fellow humans, in the face of being harmed by them. By relating to others, we make ourselves vulnerable to the hurt that they inevitably inflict on us.

It is a long and often difficult road, which travails through truth and justice and aims at the restoration of broken relationships (Anusiem, 2011:126). Forgiveness is thus very necessary as it gives rise to social harmony, which, in turn, is perhaps the greatest good for the community.

Politically, the Amnesty Act (2000) in Uganda provides a space for those formerly involved in the northern Uganda conflict by pardoning them. In northern Uganda, forgiveness has largely been observed as a process occurring between former perpetrators and their victims or affected populations. Many people have recognised 
that members of former armed groups, including some leaders of the LRA, were forcefully abducted and were therefore victims (Finnegan, 2010). In the community, both religious and traditional leaders are active in the peace process and have been leading proponents of indigenous justice mechanisms (McClaine, 2010) and indeed forgiveness.

In her study, McClaine reported that several youth and women believed that the church was a place to go and forget about the past. In fact, McClaine recommends that programming activities must exercise sensitivity particularly when engaging in activities that may bring up painful memories (McClaine, 2010). People are often instructed to forgive and forget by local counsellors, religious and traditional leaders and elders in the community. Many social scientists working in this field, however, remain concerned that political leaders can manipulate a situation to create false reconciliation and impose the 'forgive and forget' notion on the people (Hamber, 2007:119) with serious individual and community level mental and psychological consequences, and therefore such advice must be used carefully and in the right context.

\section{Background to the Forgiveness Project and Methods of Study}

The Forgiveness Project that started in April 2010 was a collaborative study bringing together scholars and researchers from Gulu University in northern Uganda, Aarhus University and the University of Copenhagen in Denmark. The project was set-up as part of an idea of an artiste, Tove Niholm, who drew her inspiration from the works and writings of the famous German Philosopher Hanna Arendt who discussed much about forgiveness. For Arendt, forgiveness creates miraculous new beginnings by freeing both the forgiver and the forgiven from the consequences of the wrong (Allers, 2011).

As northern Uganda began to experience relative peace, it became a central focus of this study to explore people's perceptions and notions of forgiveness and uncover the ramifications/implications of forgiveness for interpersonal relationships, reconciliation and sustainable peace. We did not wish to promote a baseless desire for a better world in northern Uganda. Rather, we attempted to unearth certain possibilities of building a sustainable peace by creating a kind of inspiration in people to come to talk about their past and show others that it no longer had a hold on them because they have/had forgiven those who wronged them. We agree with Finnegan (2010:439) that forgiveness presents an alternative mechanism for the Acholi people to get accountability for wrongs committed without necessarily incriminating members of their own community.

We examined aspects and processes of forgiveness at the individual level and how these could impact on fostering reconciliation and peace at the collective/community level in northern Uganda. The objectives of the study were:

- To explore the nature and processes of forgiveness in post-conflict northern Uganda and enhance the creation of space within which people can forgive and be forgiven;

- To determine how individuals cope with or manage wrongs/offences in their daily lives;

- Extract Acholi notions about forgiving, forgetting and remembrance in relation to social harmony and peacebuilding.

The study employed a combination of qualitative methods for data collection in Awach sub-County and Gulu Municipality in Gulu District. Using the snowball method, the 
researchers identified adults, both male and female of varied ages, who were willing to share a personal forgiveness experience. The criteria for participation were that one had experienced a significant wrong and felt confident that he/she had processed the wrong, moved beyond the hurt feelings and had forgiven the offender. The purpose of the project was carefully explained to each participant and his/her consent for voluntary participation was requested. Each account was audiotaped, either in English or Luo, with the researcher asking guiding and explorative questions.

The recordings, which lasted 15-60 minutes, were later transcribed in English for analysis. These recordings were carefully edited into clips of 3-6 minutes each, with clear narrations capturing the wrong, the process and impact of forgiveness. The editors took care to remain true to the core of each account and in order to protect the identity of the individuals, pseudonyms have been used in the findings section.

The edited accounts were made available to the public in Awach through a sound installation system in a former IDP camp hut, where people could come and listen to them. It was anticipated that when someone listened to an account and was 'moved by it', that person would be able to reflect on his or her own life, possibly forgive others and ask for forgiveness. This method has also made it possible for some listeners to record their own accounts. By March 2012, a total of thirty-five accounts of forgiveness (in English or Luo) were recorded and transcribed in English for analysis. The researchers also carried out sixteen in-depth interviews with key informants and selected members of the community from relevant institutions that have experience with peacebuilding in northern Uganda, including civic leaders, elders, religious leaders and representatives of NGOs. Two Focus Group Discussions with a group of elders from Awach were also carried out.

The findings of the study have been shared at three radio talk shows and 'mobile outreaches' where the researchers reached communities at Parish and village level. Discussions are held with listeners about what they thought about the project and its aims and objectives. The following account is an example of several forgiveness accounts that were recorded.

\section{A case of abduction}

When I was arrested by the LRA, one of the soldiers was following me, he kicked me down, that I was not walking, when we reached some area they caught four goats, one jerrican full of beans, uprooted four cabbages from people's gardens, that I should carry when I told him that would not be possible to carry....he jumped and hit me with the baton of his gun and said "if you were joking, you will mention my mother's name". I kept quiet. We then started moving, when I fell down, the same man came and told me "the beans you are carrying and pouring down is our life, so if you are pouring the beans, it is like you are trying to play with our lives and it is the same as playing with Mr Kony.

That man, if he wanted something he would come and pick me to do it and he would tell me that if I was tired and my legs are swollen, I should tell him so that they take me to the hospital or else they release me yet he was meaning killing me so that I rest forever. We continued walking and we met the Government soldiers where everyone took different directions. I got lost for one week in the bush. I would move and could not find what to eat. 
Sometimes, you would find only one papaya fruit remaining on the tree, unripe, the left over cassava, which was eaten by wild animals. Sometimes, you would walk for two days without getting water, sometimes you would find the remains of human beings, until when I reached home then started staying well.

One day I met this man who was after me from the bush and he came and greeted me I even noticed him but I think he thought I didn't have any good feelings for him. Then I thought to myself that maybe when he was doing those things, he did not know what he was doing. Tears rolled down my cheeks then the feeling of forgiveness came and when he asked for forgiveness, I forgave him. As we talk now, we are close to each other, most of the time we sit together. I do not have any bad feelings for him and whatever I had in my mind I have thrown them away, like a wound which has healed, so if you say you open the topic by talking about it, it means that you are reopening the wound in him or in me and it may bring back bad memories.

I request people who have gone through this difficulty, you should not put it first because it is not the end of the world. You suffer but afterwards you will be okay. There is a saying that when you started your life with suffering you end up in peace and if you started with enjoyment you end up with pain. I request people not to have a bad heart for whatever suffering he or she could have gone through in northern Uganda.

\section{I forgive to forget: recounting experiences of forgiveness, reconciliation and healing}

From the discussions and the accounts recorded, we learnt that forgiveness means different things to different people. For most, forgiveness means, "letting go" (of interpersonal difficulties) and moving on with life, while for others, it is letting go of a grudge or burden that one has in his/ her heart about a painful experience. One phrase that kept recurring was "keeping/holding someone/something in my heart." This is a phrase that the Acholi people use to describe having a grudge with someone or a heavy burden. When you keep someone in your heart it means that person has wronged or hurt you and the burden of the hurt is heavy until the moment of release through the act of forgiving the offender if one so chooses.

\section{"Forgiveness comes from the heart"}

As Finnegan (2010) points out, agency and control are very important issues not to be excluded from the forgiveness discourse. Forgiveness is indeed a personal choice even when there are institutions and other individuals who help to foster the process. One respondent, George, for instance, is quoted as having said:

$[\ldots]$ forgiveness came to my heart itself... without anyone telling me that you forgive those who have wronged you...

Many of the participants indicated that someone had to begin the process of forgiveness. It could have been initiated by oneself, a parent, an elder of the community and for some, influences of religious teachings. At any rate, whatever or whoever initiates the process, it is the individual who ultimately exercises his or her own personal choice to forgive someone who wrongs him/her, since forgiveness as several participants pointed out, "comes from the heart". An apology for a wrong committed often accelerates the process of forgiveness or at least makes it a little easier on the forgiver.

As McCullough and Witvliet (2002) stated, people are generous and more willing to forgive apologetic transgressors. One participant, Michael, who realised that he was now living with his former abductor in the same student hostel insisted that "...I think that it is necessary that you recognise me at this time..." when the latter tried to avoid and ignore the issue. And as one key informant put it: 
All in all, forgiveness should move together with an apology of what might have gone wrong and caused the conflict... it is not easy to forgive without the apology of the wrongdoer.

And according to George,

If someone has done wrong to you... he or she apologises... ahh my friend I'm sorry...forgive me...he or she has to apologise to you so that the forgiveness you are going to give is an everlasting one.

Staub et al. (2005) also believe that forgiveness without acknowledgement of responsibility for the offence may present challenges and be harmful to any relationship. However, letting go of the past wrong and creating a good relationship with the person who wronged you involves positive attitudes towards the offender. Forgiveness is personal and must be genuine. According to Paul, who told us his story:

[W] hat lies inside one's heart, no one knows. We should not be convinced by the smiles someone gives you, the white teeth that appear in his mouth do not mean it is good to believe him or her.

But George who was formerly abducted believes that "... if you have forgiven, you have to forgive forever" or else a heavy burden remains in your heart. He clearly stated that even though he had let go of the wrong, narrating it was like opening a wound "...and it brings many things even on him and even on you...." This speaks to our interconnectedness where, as the Ubuntu notion explains, "people are people through other people'. George and Chris both told us that rehearsing the painful experience and memory or keeping anger only brings pain not only to oneself but to others in the community as well.

Forgiveness is indeed a process; and like any other process, it must go through certain stages. For our participants, some very vital stages in the forgiveness process included: the offender acknowledging the wrong committed; the offender apologising after committing a wrong; forgiveness must come from one's heart, be genuine and not forced by a third party; and the victim letting it go or releasing it from his or her heart. The final stage in the forgiveness process involves the forgiver letting the forgiven know or realize from verbal communication or in the acts of the forgiver that the aggrieved had forgiven the wrongdoer for his/her act.

\section{Peaceful co-existence through the acceptance of one's humanity}

'People make mistakes'. 'To forgive is divine.' These are adages that people have believed for ages and still hold true even in grave times such as war, violence and shattered social relationships. Many experiences of war and the memories of it tell a gruesome tale. When we encountered people whose accounts directly related to the war, what was particularly interesting was that no one talked about forgiving those directly responsible for it e.g. the LRA or the government soldiers. Instead, a close relation, friend or neighbor was always responsible for the wrong committed. One example is Caroline who blamed her father for her long suffering in captivity because he did not believe in sending girls to school and so she was abducted on her way to a shop one day. She held on to this memory for a long time and she describes it as having consumed her and embittered the relationship between herself and her father until she finally 'let it go' many years later.

There were several acts of forgiveness with similar experiences and those who told the accounts believed that the people who committed the wrongs were victims of 
circumstance themselves, and indeed all the forgivers preferred to seek out the humanness in the offender. Luka who had been abducted by someone he had gone to school with put it this way: "...he was in darkness and now he has seen the light." Because of this 'generosity' towards the offenders, we believe that many people in Gulu District have been able to co-exist with their former and indeed current 'tormentors'. We argue that this recognition by the aggrieved of the humanness of those who violate them is central to the stability and unity in northern Uganda as communities continue to rebuild their lives and their society.

We state it most vehemently that forgetting in the sense in which we use it in the everyday, is not about having 'selective amnesia'. For most participants, forgetting is more about accepting the past without seeking revenge, knowing that holding on to it brings more pain than peace and therefore moving forward is perhaps the better option. According to Pam

[Y]ou still think about it. It comes back...but if I managed to let go of

it...really haunted me for a very long time...this is not worth it.

\section{Promoting peace and reconciliation in northern Uganda}

People who felt wronged or hurt by others experienced a lot of anger, resentment and/or hatred towards their aggressors. Consequently the victims of a wrong were for a longtime pre-occupied with their experience and the associated anger. Some of them experienced a lack of freedom to move on and/or progress with their lives. For one particular woman we interviewed, her feeling of having been betrayed by her parents, who were both deceased for many years, made her resort to alcohol abuse in order to cope with her agony. Some descriptions of these wrongs include a "wound in the heart", "burning heart", and "no happiness".

In some cases the wrongs that victims experienced intensified their perceived family disunity and feared that this would lead to death, bad luck, curses or physical harm in them personally. For instance, Sam narrates his experience with his father who stopped paying his school fees when he brought a new wife to the home. He instead paid fees for the other child that the stepmother came with and Sam went on to have a hard life. "My studies were spoilt, I was very angry, I felt a lot of anger and that was why I went to my mother's homeland".

When we asked the participants to describe how forgiveness had impacted on their lives, most of them had something positive to say about it. Forgiveness helps people to let go of the grudges and bitterness that they have been holding on to for a long time. Time indeed is an important element in the process of forgiveness and when people feel that they have completely let go of the bitterness that they felt inside, suddenly there is room for compassion, kindness and peace within their hearts. Forgiveness helps one to feel free or have freedom from hatred; anger, vengeful feelings and bitterness that hold them back. In a way, this helps them to lift the burdens from their hearts, and be free from the past. For instance George forgave the man who abducted and mistreated him while in the ranks of the LRA.

I do not have any bad feelings for him, whatever I had in my mind I have thrown them away, like a wound, which has healed.

Another respondent said:

When I set someone free from my heart, release them from my heart when they have wronged me, it makes me feel free. 
Orcutt et al (2005) also agreed that the realisation that continued focus on the injury can only lead to more suffering on the part of the victim.

Like Wade and Worthington (2005), we believe that forgiveness must be present for reconciliation to occur. When one forgives, he or she feels at peace and harmony with the family and kinship, and can easily relate and interact freely with family members without holding any grudges. For many participants the act of sharing meals, visiting each other's homes and families is a very important step to show that forgiveness has actually taken place. This positive change in behaviour towards the wrongdoer is vital. Noteworthy however, is that it does not necessarily follow that an act of forgiveness leads to reconciliation (Wade \& Worthington, 2005). For Josephine whose husband had abused and neglected her for a long time, a difficult decision faced her. In the end, all she said to him was "...I've forgiven you for all that you have done, but I cannot come back to you..."

Forgiveness also creates opportunities for the future of those who forgive as well as their own development. All the participants believed that when one forgives, and releases grief from his/her heart, they are freed from that burden and a higher force rewards them for the selfless act of forgiving someone. Josephine believed that,

Through forgiveness, people can achieve more goals than what they want in their life, because once you hold someone into your heart, however much you try, ... you will not succeed.

For those who are religious or spiritual, it is believed that forgiveness helps in warding off bad luck or bad spirits from family members and others in the community.

Throughout our discussions, a recurring rhetoric was that forgiveness brings healing, personal freedom and lifts heavy burdens from the heart. This is significant for both intrapersonal and interpersonal relationships. It goes without saying that some of our participants committed a number a heinous wrongs, regretted them and may or may not yet have asked for forgiveness. How then does one live with oneself when they are back home from the bush and living with the very people they aggravated? According to Chris, forgiving yourself is the first step to healing in the mind and the heart. This was an important for attaining personal peace within oneself.

For Dora who forgave her co-wife for humiliating her when she returned from captivity by the LRA, forgiveness has led to peace between them and in the home. In her words, "I thought in my heart it was useless to keep the record of the wrongs...it spoils the relationship among people..." This was a crucial step in creating peace between two wives who fought constantly and ultimately, it brought peace to the homestead. Tom aptly summarized the need for reconciliation and restoration of broken relationships this way:

Since they were my relatives I could not hold a grudge with them for long. Since I am the uncle I could not just get angry...I was capable of cursing and blessing them...I just felt that soldiers had almost finished everyone in our family and if I was to curse them again I would finish the whole family."

\section{Conclusion}

We reiterate that 'forgetting' in this context is not denying or being amnesic toward a wrong that one has suffered. Rather, forgiveness entails acceptance of the wrong as having occurred, processing it and letting it go in order for one to move on with one's 
life. Through forgiveness, a space is created for perpetrators of crimes to be reintegrated in the northern Ugandan community and be seen as fellow human beings most of whom were also victims of traumatic circumstances. An interesting finding is that when asked to tell a forgiveness story, most people talked about those close to them and no direct story was told about those responsible for the long war.

None of our research participants reported that their individual acts of forgiveness led them to forget their traumatic experiences. Rather, participants reported the positive experiences related to the lifting of heavy burdens of storing negative affects, anger and resentment associated with trauma. As negative affects associated with traumatic experiences dissipate, it appears that victims of wrongs and hurts "forget" that they have ever been wronged and they lead normal lives with their close relatives and family members. Indeed this supports the notion of our being connected with others in our communities, i.e. 'people are people through other people'.

Thus forgiving to forget enables victims and perpetrators to draw strength from their painful memories and shape a lasting peace in their relationships. The challenge now remains for translating these findings to the peace building process at the wider community level in post-conflict northern Uganda. A successful translation of these findings appears to offer hope for stability and unity at both the community and national levels in Uganda. Already, there has been an established link between this project and other projects that are in the business of building peace in Uganda. One example is the Uganda Museum that is currently showcasing some 'voice accounts' collected as part of their 'Roads to peace in northern Uganda Project', a project that is hinged on cultural reconstruction and memorialisation of the events that took place during the war.

It is widely recognised that forgiveness traverses the time continuum creating a connectedness. This connectedness appears to lead to some kind of social healing that is necessary for the attainment of a sustainable peace. Relationships are the crux of peacebuilding, elemental to the creation of a shared future. Should people hold on to their 'primordial' rights to vengeance and chosen traumas, this will lead to renewed cycles of violence that will mar these relationships and ultimately the goal of peace. It is our hope that by not forgetting what happened, acknowledging that it happened, and forgiving, peace can be achieved in northern Uganda. We believe that the integration of memory in the lived experience of individuals through shared accounts of forgiveness has an important place in promoting peace in northern Uganda.

And as Desmond Tutu (1999) so correctly quotes George Santayana - "Those who cannot remember the past are condemned to repeat it."

\section{References}

Allen, Tim. (2006). Trial Justice: The International Criminal Court and the Lord's Resistance Army. Chicago: Lawrence Hill Books.

Allen, Tim., and Koen Vlassenroot, editors, (2010). The Lord's Resistance Army: Myth and Reality. London: Zed Books.

Allers, Christopher, R. (2011). Undoing What Has Been done: Hannah Arendt and Emmanuel Levinas on Forgiveness. In Forgiveness: Promise, Possibility and 
Failure, edited by Geoffrey Karabin \& Karolina Wigura, pp. 171-181. Oxford: Inter-Disciplinary Press.

Anusiem, Boniface. (2011). "The African Model of Forgiveness: A Contribution to Social Reconstruction and World Peace. In Forgiveness: Promise, Possibility and Failure, edited by Geoffrey Karabin \& Karolina Wigura. Oxford: InterDisciplinary Press.

Atkinson, Ronald R. (2009). Afterword: The Origins of the Acholi of Uganda: A Perspective on the Last Thirty Years. $2^{\text {nd }}$ Edition. Kampala: Fountain Publishers.

Avruch, Kevin and Beatriz Vejarano. (2002). "Truth and Reconciliation Commissions: A review Essay and Annotated Bibliography". OJPCR: The Online Journal of Peace and Conflict Resolution 4(2): 37-76 available at www.trinstitute.org/ojpcr/4_2recon.pdf

De Temmerman, Els. (2001). Aboke Girls: Children Abducted in Northern Uganda. Kampala: Fountain Publishers.

Dolan, Chris. (2009). Social Torture: The Case of Northern Uganda, 1986-2006. New York: Berghahn Books.

Eichsraedt, Peter. (2009). First Kill Your Family: Child Soldiers of Uganda and the Lord's Resistance Army. Chicago, IL: Lawrence Hill Books.

Fincham, Frank, D. (2000). The Kiss of the Porcupines: From Attributing Responsibility to Forgiving. Personal Relationships, 7, 1-23.

Finnegan, Amy, C. (2010). Forging Forgiveness: Collective Efforts Amidst War in Northern Uganda. Sociological Inquiry, 80(3), 424-447.

Finnström, Sverker. (2008). Living with Bad Surroundings: War, History and Everyday Moments in Northern Uganda. Durham: Duke University Press.

Graybill, Lyn, S. (2004). Pardon, punishment, and amnesia: three African post-conflict methods. Third World Quarterly, 25(6), 1117-1130.

Green, Mathew. (2008). The Wizard of the Nile: The Hunt for Africa's Most Wanted. London: Portobello Books, London, UK: Zed Books.

Hamber, Brandon. (2007). "Forgiveness and Reconciliation: Paradise Lost or Pragmatism?" Peace and Conflict: Journal of Peace Psychology. 13(1), 115125.

Hamber, Brandon and Richard, Wilson. (2002). Symbolic closure through memory, reparation and revenge in post-conflict societies. Journal of Human Rights $1(1)$. 
Larocco, Steve. (2011). "Forgiveness: A Quiet Assault on the Malicious." In Forgiveness: Promise, Possibility and Failure, edited by Geoffrey Karabin \& Karolina Wigura, pp. 3-12. Oxford: Inter-Disciplinary Press.

McClain, Lindsay. (2010). "The Art of Creative Conflict Resolution: A Critical Evaluation of Approaches to Post-Conflict Reconstruction in Northern Uganda" Pursuit: The Journal of Undergraduate. 1(1): 89-101.

McCullough, Michael, E. and Charlotte, Witvliet. (2002). The Psychology of Forgiveness. In Handbook of Positive Psychology edited by, C. R. Snyder \& S. J. Lopez pp. 446-458. New York: Oxford.

Mercedes Barros. (2001). "Reshaping the Present and Constructing the Future through remembering the Past. Human Rights and Human Welfare. 1(3): 7-12.

Orcutt, Holly, K., Scott, M., Pickett, and Brooke, Pope. (2005). Experiential Avoidance and Forgiveness as Mediators in the Relation Between Traumatic Interpersonal Events and Posttraumatic Stress Disorder Symptoms. Journal of Social and Clinical Psychology, 24(7), 1003-1029.

Ovuga Emilio, Oyok T, and Emmanuel, Moro, B. (2008). Post-traumatic stress disorder among former child soldiers of the Lord's Resistance Army (LRA) attending a primary and rehabilitation school in northern Uganda, African Health Sciences, 8(3): 136-141.

Staub, Ervin, Laurie, A. Pearlman, Alexandra Gubin, and Athanase, Hagengimana. (2005). Healing, Reconciliation, Forgiving and the Prevention of Violence After Genocide or Mass Killing: An Intervention and Its Experimental Evaluation in Rwanda. Journal of Social and Clinical Psychology, 24(3): 297-334.

Summerfield, Derek. (2002). Effects of War: Moral Knowledge, Revenge, Reconciliation and Medicalised Concepts of "Recovery." BMJ, 325, 11051107.

Swartz, Leslie and Gerard Drennan. (2000). The Cultural Construction of Healing in the Truth and Reconciliation Commission: implications for mental health practice. Ethnicity and Health, 5(3/4), 205-213.

The Amnesty Act. (2009). An Act of Forgiveness. Kampala: The Amnesty Commission.

Theidon, Kimberly. (2000). "How we learned to Kill Our Brother”?: Memory, Morality and reconciliation". Bull.Inst. Fr. Étudenes.andines. 29 (3), 539-554.

Toussaint, L. Loren, Williams, D. R., Musick, M. A., \& Everson, S. A. (2001). Forgiveness and Health: Age Differences in a U.S. Probability Sample. Journal of Adult Development, 8(4), 249-257.

Tutu, Desmond. (1999). No Future Without Forgiveness. London: Rider.

Volkan V. (2004). Blind Trust: Large Groups and their Leaders in Times of Crisis and Terror. 
Charlottesville: Pitchstone Publishing.

Wade, G. Nathaniel and Everett L. Worthington. (2005). In search of a Common Core: A Content Analysis of Interventions to Promote Forgiveness. Psychotherapy: Theory, Research, Practice, Training. 42(2), 160-177.

Witvliet, Charlotte, Thomas, E. Ludwig, and Kelly L.V. Laan. (2001). Granting Forgiveness or Harbouring Grudges: Implications for Emotion, Physiology and Health. Psychological Science, 12(2), 117-123. 